\title{
The Influence of Job Discipline and Job Load Toward Teacher's Performance In Muhammadiyah 1 Krian Elementary School
}

\author{
$1^{\text {st }}$ Pristiandi Teguh Cahya \\ Master Program Study of Human \\ Resource Development, Postgraduate \\ School of Universitas Airlangga \\ Surabaya, East Java, Indonesa \\ anditeca@yahoo.co.id
}

\author{
$2^{\text {nd }}$ Novri Susan \\ Lecturer of Sociology, Faculty of Social \\ Science and Political Science, \\ Universitas Airlangga Surabaya \\ East Java, Indonesia \\ novri.susan@yahoo.com
}

\begin{abstract}
Muhammadiyah 1 Krian Elementary School is one of the selected schools in Krian or Sidoarjo District in the western part. Nevertheless, the culture of teacher discipline is still lacking in the traditional school culture culture, so school performance should be optimized to be less dynamic. Based on observations and data obtained found some problems, both internal and external aspects. The problem is closely related to teacher performance, student achievement, culture and school habit, learning innovation, and not maximal communication and cooperation with outsiders. Teacher's performance is also determined by high work discipline. Thus schools that are in the process of learning and teaching grow discipline, will serve as the shaper of individual values and norms, self-mastery, attitudes and responsibilities for teachers. The lack of discipline of teachers in performing tasks, such as coming to school late, being ignorant towards students resulted in low quality of learners. Based on the above problems, encouraging researchers to examine the influence of job discipline and job load toward teacher's performance in Muhammadiyah 1 Krian Elementary School..
\end{abstract}

Keywords—Job Discipline; Job Load; Performance; Teacher

\section{INTRODUCTION}

Teachers are the central figure of education in the effort to prepare the nation's cadre in the future, the key to successful educational reform. Among the factors that influence the learning process and outcomes of the students, the teacher factor gets first and foremost attention, because the good of the implementation of a curriculum ultimately depends on the activity and creativity of the teacher in describing and realizing the curriculum direction. Therefore, teachers must be professional in carrying out their duties. Muhammadiyah 1 Krian Elementary School is one of the selected schools in District of Krian. Nevertheless, the culture of teacher discipline is still lacking in the traditional school culture culture, so school performance should be optimized to be less dynamic.

Based on observations and data obtained found some problems in Muhammadiyah 1 Krian Elementary School, both internal and external aspects. The problem is closely related to teacher performance, student achievement, culture and school habit, learning innovation, and not maximal communication and cooperation with outsiders. In contrast to the fact that since 2012, there are some things that hamper relating to the professional performance of teachers, it is based on data picture related to the number of teachers, learning strategy and evaluation, compensation, accumulation of attendance level, labor turnover, to the achievement of the work produced by teachers of Muhammadiyah 1 Krian Elementary School.

Discipline as a condition created and formed through the process of a series of behaviors that show the values of obedience, obedience, regularity or discipline [1]. The low disciplinary work of teachers will result in poor quality of education in schools. Discipline has a very important role in directing human life to achieve its goals and success in work, because without any discipline then someone does not have a benchmark about what is good and bad in his behavior. The lack of work discipline of Muhammadiyah 1 Krian Elementary School can be seen in table 1.1 below:

TABLE I. ACCUMUlation LEVEl of TEACHERs’ ATtENDANCE MUHAMMADIYAH 1 KRIAN ELEMENTARY SCHOOL IN 2017

\begin{tabular}{|l|l|l|l|l|}
\hline \multirow{2}{*}{ Year } & \multirow{2}{*}{$\begin{array}{l}\text { Percentage of } \\
\text { Attendance (\%) }\end{array}$} & Percentage of Absence (\%) \\
\cline { 3 - 5 } & 96,4 & Permission & Sick & Unreason \\
\hline 2011 & 96,2 & 0,8 & 2,2 \\
\hline 2012 & 97,2 & 1,2 & 0,6 & 1,8 \\
\hline 2013 & 98 & 0,6 & 2 & 2,4 \\
\hline 2014 & 96,8 & 0,2 & 1,4 & 1,2 \\
\hline 2015 & 96,2 & 1,2 & 1,2 & 1,8 \\
\hline 2016 & $\mathbf{9 6}$ & $\mathbf{1 , 4}$ & $\mathbf{1 , 8}$ & $\mathbf{2 , 6}$ \\
\hline
\end{tabular}

Teacher's performance is also determined by high work discipline. Thus schools that are in the process of learning and teaching grow discipline, will serve as the shaper of individual values and norms, self-mastery, attitudes and responsibilities for teachers. The lack of discipline of teachers in performing tasks, such as coming to school late, being ignorant towards students resulted in low quality of learners. Workload factors are a factor encountered by teachers in the workplace environment.

The work load regulated in the Regulation of the Minister of National Education No. 30 of 2011 for some teachers there 
are increasing the workload, there is also for the teacher does not cause workload. The burden of work outside school hours that have been arranged as a form of contribution to school, education, religion, and even the community into a separate burden for teachers, it can be seen in table 1.4 below:

TABLE II. LIST OF ACHIEVEMENT AND TEACHERS’ WORK IN 2017

\begin{tabular}{|l|l|l|l|l|l|l|l|}
\hline Type of & \multicolumn{7}{|c|}{ Achievement Number in Year of } \\
\cline { 2 - 9 } Achievement/Work & $\mathbf{2 0 1 1}$ & $\mathbf{2 0 1 2}$ & $\mathbf{2 0 1 3}$ & $\mathbf{2 0 1 4}$ & $\mathbf{2 0 1 5}$ & $\mathbf{2 0 1 6}$ & $\mathbf{2 0 1 7}$ \\
\hline Scientific Papers & 1 & 2 & 1 & 3 & 3 & 4 & $\mathbf{7}$ \\
\hline Blog & 1 & 1 & 3 & 2 & 5 & 6 & $\mathbf{1 0}$ \\
\hline $\begin{array}{l}\text { Competition in } \\
\text { City/District Level }\end{array}$ & 4 & 5 & 5 & 3 & 4 & 5 & $\mathbf{8}$ \\
\hline $\begin{array}{l}\text { Competition in } \\
\text { Province Level }\end{array}$ & 1 & 0 & 0 & 2 & 1 & 2 & $\mathbf{2}$ \\
\hline $\begin{array}{l}\text { Competition in } \\
\text { National/International } \\
\text { Level }\end{array}$ & 0 & 0 & 0 & 0 & 1 & 1 & $\mathbf{2}$ \\
\hline Interviewees & 34 & 39 & 28 & 30 & 42 & 41 & $\mathbf{4 6}$ \\
\hline Speaker & 69 & 72 & 83 & 61 & 82 & 90 & $\mathbf{9 4}$ \\
\hline $\begin{array}{l}\text { Participant/Contributor } \\
\text { in Civil Organization }\end{array}$ & 5 & 11 & 11 & 18 & 14 & 16 & $\mathbf{2 0}$ \\
\hline $\begin{array}{l}\text { Administrator of } \\
\text { Muhammadiyah in } \\
\text { many levels }\end{array}$ & 4 & 3 & 3 & 6 & 6 & 7 & $\mathbf{1 2}$ \\
\hline
\end{tabular}

The condition is apparently inversely proportional to the teacher turnover labor that occurred during 2011 to 2017 , as shown in table 1.5 below:

TABLE III. LABOR TURNOVER OF TEACHER IN 2017

\begin{tabular}{|l|l|l|l|l|}
\hline Year & $\begin{array}{l}\text { Start } \\
\text { Count }\end{array}$ & $\begin{array}{l}\text { Incoming } \\
\text { Teacher }\end{array}$ & $\begin{array}{l}\text { Outcoming } \\
\text { Teacher }\end{array}$ & $\begin{array}{l}\text { Last } \\
\text { Count }\end{array}$ \\
\hline 2011 & $\mathbf{3 9}$ & 1 & 0 & 40 \\
\hline 2012 & 40 & 0 & 0 & 40 \\
\hline 2013 & 40 & 3 & 0 & 43 \\
\hline 2014 & 43 & 0 & $\mathbf{1}$ & 42 \\
\hline 2015 & 42 & $\mathbf{4}$ & 0 & 46 \\
\hline 2016 & 46 & 0 & 0 & 46 \\
\hline 2017 & 46 & 0 & 0 & $\mathbf{4 6}$ \\
\hline
\end{tabular}

Based on the above problems, encouraging researchers to examine the influence of job discipline and job load toward teacher's performance in Muhammadiyah 1 Krian Elementary School.

\section{A. Research Problem}

1. Are the job discipline and job load significantly influence toward teacher's performance in Muhammadiyah 1 Krian Elementary School partially?

2. Are the job discipline and job load significantly influence toward teacher's performance in Muhammadiyah 1 Krian Elementary School universally?

\section{LITERATURE REVIEW}

\section{A. Teacher's performance}

Performance is a form of behavior of a person or organization with achievement orientation. One's performance is associated with several factors such as: ability, capacity, held, intencive, enviroment and validity (Notoatmojo, 2009)[2]. Performance of teachers have certain specifications, teacher performance can be seen and measured based on the specifications / criteria of competence that must be owned by each teacher. In relation to teacher performance, the form of behavior in question is the activity in the learning process is how a teacher planning a lesson learned, carry out learning activities and assess learning outcomes.

\section{B. Job Discipline}

Simamora (2004) states that discipline is a procedure that corrects or punishes subordinates for violating rules or procedures [3]. Discipline is a form of employee self-control and regular execution and shows the level of earnestness of work teams within an organization. According to Alma (2003) said that discipline can be interpreted as an attitude of obedience, behavior, and deeds in accordance with company regulations both oral and written.

In line with the above opinion, Fathoni (2006) defines discipline as an awareness and willingness to obey all organizational rules and prevailing social norms[4]. From the above understanding can be concluded that the discipline of work is the attitude and action of teachers in obey all the guidelines and regulations that have been determined for the achievement of organizational goals. Discipline is closely related to teacher behavior and relates to teacher performance. According Hasibuan there are several indicators that can relate the level of discipline of an organization's employees that objectives and abilities, leadership, remuneration, justice, supervision attached[5].

\section{Job Load}

Everly and Girdano state that job load is a situation where workers are faced with tasks that must be completed at any given time [6]. Another category of workload is a combination of quantitative and qualitative job loads. Quantitative job load is caused by too much or little task. While the workload is qualitative, if the worker feels unable to perform the task or duty does not use the skill or potential of the worker [7]. A job load is a set or number of activities to be completed by an organizational unit or holder of office within a certain timeframe [8].

The external factor of job load is the job load that comes from outside the worker's body. The aspect of external job load is often referred to as a stressor. According to Manuaba, which includes external job load are: 1.) Tasks; 2.) Organization of work; 3.) Job environment. Internal factor of job load is a factor derived from within the body itself as a result of the reaction of 
the external of job load [9]. The reaction is known as a strain. In summary, the internal factors, includes are: 1.) Somatic factor (i.e. sex, age, body size, health condition, nutritional status); 2.) Psychic factors (i.e. motivation, perception, trust, desire, satisfaction, and so forth).

\section{RESEARCH METHOD}

In this study, researchers used a research design that is explanative. Explanative research is research that seeks to explain or explain an event based on data that aims to find whether there is a relationship between two phenomena or more. So this research tries to find out whether there are influence of job discipline and job load toward teacher's performance in Muhammadiyah 1 Krian Elementary School. Using total sampling for all the teachers in that school. The research instrument used in this research is based on the theory of job discipline and job load as independent variables and the theory of performance as dependent variable.

Data analysis techniques used are the classical assumption test, among others: 1.) Multicolonierity Test; 2.) Heteroscedasticity Test; 3.) Autocorrelation Test; 4.) Normality Data Test. In testing the hypothesis in this study using the t-test and Coefficient of Determination $\left(\mathrm{R}^{2}\right)$ to determining the hypothesis.

\section{DiscusSiON}

Multicollinearity test indicates a strong correlation between independent variables in the regression model. Detection of presence or absence of multicollinearity is done by looking at tolerance values and Variance Inflation Factor (VIF) values. If the VIF value $<10$ and tolerance $>0.1$ then the regression model is free from multicollinearity. Here is the value of VIF generated by regression model:

TABle IV. The Result of Multicollinearity: Primary Data 2018

\begin{tabular}{|l|l|l|l|}
\hline Variable & Tolerance & VIF & Result \\
\hline Job Discipline $\left(\mathrm{X}_{1}\right)$ & 0.729 & 1.371 & $\begin{array}{l}\text { There is no } \\
\text { multicollinearity }\end{array}$ \\
\hline Job Load $\left(\mathrm{X}_{2}\right)$ & 0.729 & 1.371 & $\begin{array}{l}\text { There is no } \\
\text { multicollinearity }\end{array}$ \\
\hline
\end{tabular}

Based on table 4 above it is known that all VIF values in both independent variables in the regression model are less than 10 and tolerance $>0.1$, so it can be concluded that free regression model of multicollinearity thus non-multicollinearity assumption has been fulfilled.

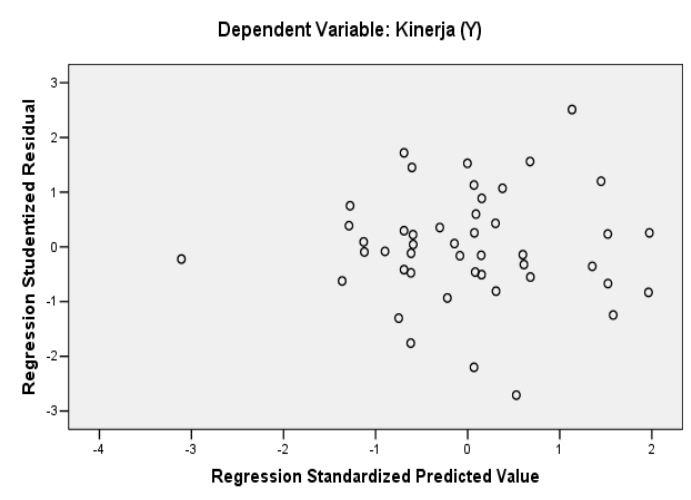

Fig. 1 The Result of Heteroscedastisity Test with Scatterplot : Primary Data, 2018

Heterocedasticity test is used to test whether or not the variant between residual observations with each other. If the residual variant is not homogeneous, there is heteroscedasticity. A good regression model does not contain heteroscedasticity, in other words the residual variant should be homogeneous. Testing whether or not heteroscedasticity is performed using a scatterplot between the predicted value of the bound variable (ZPRED) and its residual (SRESID). If scatterplots produce dots that do not form a particular pattern, then there is no heteroscedasticity. Here are the results of heteroscedasticity test:

From Figure 1 note the points do not form a particular pattern, which is marked with spots spread above and below the zero axis $\mathrm{Y}$. This result shows spearman correlation results in testing the model no heteroscedasticity. In addition to using the graph, heteroscedasticity test also performed with spearman rank correlation, the following rank heteroscedasticity:

TABle V. The Result of Heteroscedasticity Test: Primary DATA, 2018

\begin{tabular}{|l|l|l|l|}
\hline Variable & $\begin{array}{l}\text { Koefisien } \\
\text { Rank } \\
\text { Spearman }\end{array}$ & Significancy & Information \\
\hline Job Discipline $\left(\mathrm{X}_{1}\right)$ & 0.161 & 0.285 & $\begin{array}{l}\text { There is no } \\
\text { heteroscedasticity }\end{array}$ \\
\hline Job Load $\left(\mathrm{X}_{2}\right)$ & 0.271 & 0.069 & $\begin{array}{l}\text { There is no } \\
\text { heteroscedasticity }\end{array}$ \\
\hline
\end{tabular}

Based on table 5 above can be seen that the value of Spearman rank correlation significance of independent variables on the model more than 0.05 , so it is concluded that there is no heteroscedasticity in the regression model, thus assumption non heteroscedasticity has been fulfilled.

Autocorrelation shows that in a linear regression model there is an intrusion error over a period of time with an error in the previous time period. A good regression model is free from autocorrelation. Detection of whether or not autocorrelation can be performed using Durbin Watson (DW-test). An observation is said to be no autocorrelation if the value of Durbin Watson 
$\mathrm{dU}<\mathrm{dw}<4-\mathrm{dU}$. Here is the value of Durbin Watson generated from the regression model:

TABle VI. The Result of Durbin-Watson Value: Primary Data, 2018

\begin{tabular}{|l|l|l|l|}
\hline $\begin{array}{l}\text { Underline } \\
\text { Limit }\end{array}$ & $\begin{array}{l}\text { Durbin } \\
\text { Watson }\end{array}$ & $\begin{array}{l}\text { Upline } \\
\text { Limit }\end{array}$ & Information \\
\hline 1.62 & 1.88 & 2.38 & Non autocorrelation \\
\hline
\end{tabular}

Based on table 6 it is known that Durbin-Watson (DW) regression model is at du and 4-du interval. So from these results indicate no autocorrelation occurs in the regression model, or assumption of free autocorrelation in regression model is met. The residual normality test procedure was performed by kolmogorov smirnov test. If the value of significance resulting from the kolmogorov smirnov test $>0.05$ $(\alpha=5 \%)$, then the residual regression model is normally distributed. From the calculation results obtained significance value of kolmogorov smirnov residual test as follows:

TABLE VII. The RESUlt OF RESIDUAL NORMALITy: Primary DATA, 2018

\begin{tabular}{|l|l|l|}
\hline Kolmogorov Smirnov Z & Significancy & Information \\
\hline 0.631 & 0.821 & Normal \\
\hline
\end{tabular}

Table VII shows that the Kolmogorov-smirnov residual test yields a significance value of $0.821>0.05$, it can be concluded that the residual regression model is normally distributed, thus the assumption of residual normality has been met. This situation can also be strengthened by using the Normal Probability Plot. If the points on the graph spread around the diagonal line, then it is concluded that the assumption of normality is met. The following presented Normal Probability Plot regression in this study :

Fig. 2 : The Result of Kolmogorov-smirnov Test with P-Plot : Primary Data, 2018

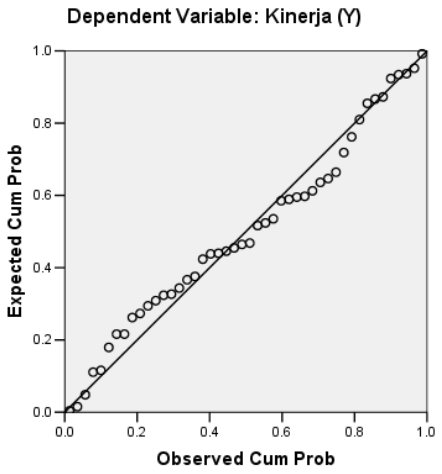

From result of regression analysis obtained by regression equation as follows:

$$
Y=1.655+0.232 X_{1}+0.252 X_{2}
$$

The explanation of the regression equation above is:

$\mathrm{a}=$ constant $=1.655$

This means that if the independent variables $X_{1}$ and $X_{2}=$ 0 , then the value of the dependent variable $(Y)$ is 1.655 . In other words, if the job discipline $\left(\mathrm{X}_{1}\right)$ and job load $\left(\mathrm{X}_{2}\right)$ do not give effect, then the teacher's performance $(\mathrm{Y})$ still has a value of 1.655 .

$\mathrm{b}_{1}=$ regression coefficient of job discipline $\left(\mathrm{X}_{1}\right)=0.232$

This means that if $X_{1}$ changes one unit, then $Y$ will change by 0.232 assuming variable $\mathrm{X}_{2}$ fixed. The positive sign on the regression coefficient value represents the direct relationship between $X_{1}$ and $Y$, meaning that if the regulator's regulatory factor is getting better, then the teacher's performance will increase by 0.232 .

$\mathrm{b}_{2}=$ regression coefficient of job load $\left(\mathrm{X}_{2}\right)=0.252$

This means that if $\mathrm{X}_{2}$ changes one unit, then $\mathrm{Y}$ will change by 0.252 assuming variable $\mathrm{X}_{1}$ fixed. The positive sign on the regression coefficient value represents the direct relationship between $\mathrm{X}_{2}$ and $\mathrm{Y}$, meaning that if the workload is higher, then the teacher's performance will increase by 0.252 .

Testing the influence of job discipline and job load toward teacher's performance in Muhammadiyah 1 Krian Elementary School yields $\mathrm{R}$ value (multiple correlation) and $\mathrm{R}^{2}$ value (coefficient of determination multiplier) as follows:

TABLE VIII. R AND R ${ }^{2}$, PRIMARY DATA, 2018

\begin{tabular}{|l|l|}
\hline $\mathbf{R}$ & $\mathbf{R}^{2}$ \\
\hline 0.597 & 0.357 \\
\hline
\end{tabular}

Based on table 8 above is known that the value of $\mathrm{R}$ obtained by 0.597 indicates that the relationship of job discipline and job load toward teacher's performance quite strong. The value of $\mathrm{R}^{2}$ obtained is 0.357 , it means that job discipline and job load have an effect toward teacher's performance is $35.7 \%$ and the rest $64.3 \%$.

Knowing the effect of simultaneously independent variable to dependent variable used F-test. With the condition if $\mathrm{F}_{\text {count }}>$ $\mathrm{F}_{\text {table }}$ and significance value $<0.05(\alpha=5 \%)$, then independent variable simultaneously have significant effect to dependent variable. The result of F-test of the influence of job discipline and job load toward teacher's performance is as follows:

TABLE IX. The RESUlt OF F-TEST: Primary DATA, 2018 


\begin{tabular}{|l|l|l|l|l|l|}
\hline Model & $\begin{array}{l}\text { Sum of } \\
\text { Squares }\end{array}$ & Df & $\begin{array}{l}\text { Mean } \\
\text { Square }\end{array}$ & F hitung & Sig. \\
\hline Regression & 1.286 & 2 & 0.643 & \multirow{2}{*}{11.922} & \multirow{2}{*}{0.000} \\
\cline { 1 - 4 } Residual & 2.319 & 43 & 0.054 & & \\
\hline Total & 3.605 & 45 & & & \\
\hline
\end{tabular}

Based on table 9 above $\mathrm{F}$-test results obtained $\mathrm{F}_{\text {count }}=11.922$ $>\mathrm{F}_{\text {table }} 3.214\left(\mathrm{df}_{1}=2, \mathrm{df}_{2}=43, \alpha=0.05\right)$ and significancy value $=0.000<0.05$, it is concluded that job discipline and job load simultaneously have a significant effect on teacher's performance Knowing partially influence of independent variable to dependent variable used t-test. Provided if $\mathrm{t}_{\text {count }}>\mathrm{t}_{\text {table }}$ and significance value $<0.05(\alpha=5 \%)$, then the independent variables significant effect on the dependent variable partially. The result of t-test of influence of job discipline and job load toward teacher's performance in Muhammadiyah 1 Krian Elementary School is as follows:

TABLE X. The ReSUlt OF T-TEST: Primary DATA, 2018

\begin{tabular}{|l|l|l|l|l|l|}
\hline $\begin{array}{l}\text { Independent } \\
\text { Variable }\end{array}$ & B & Beta & $\mathbf{t}_{\text {count }}$ & Sig. & Information \\
\hline $\begin{array}{l}\text { Work Discipline } \\
\left(\mathrm{X}_{1}\right)\end{array}$ & 0.232 & 0.373 & 2.603 & 0.013 & significant \\
\hline Work Load $\left(\mathrm{X}_{2}\right)$ & 0.252 & 0.311 & 2.174 & 0.035 & significant \\
\hline
\end{tabular}

From table 10 above can be seen, among others:

1. T-test result between work discipline to teacher's performance, yield $t_{\text {count }}=2,603>t_{\text {table }} 2.017(\mathrm{df}=43$, $\alpha / 2=0.025)$ and significance value $=0,013<0,05$. Regression coefficient of job discipline of 0.232 indicates that job discipline has a positive effect toward teacher's performance in Muhammadiyah 1 Krian Elementary School.

2. The t-test result between job load toward teacher's performance, yield $\mathrm{t}_{\text {count }}=2,174>\mathrm{t}_{\text {table }} 2.017(\mathrm{df}=43$, $\alpha / 2=0.025)$ and significance value $=0,035<0,05$. Regression coefficient of job load equal to 0,252 indicate that job load have positive effect toward teacher's performance in Muhammadiyah 1 Krian Elementary School.

\section{CONClusion}

This study is a quantitative study that examines the effect of job discipline and job load toward teacher's performance. The study was conducted on teachers of Muhammadiyah 1 Krian Elementary School using total sampling of 46 respondents. After data collection, data processing, data analysis with statistical methods. The conclusions resulting from this research include:1. ) Job discipline and job load have a significant influence toward teacher's performance in Muhammadiyah 1 Krian Elementary School partially; 2.) Job discipline and job load have a significant influence toward teacher's performance in Muhammadiyah 1 Krian Elementary School simultaneously.

\section{REFERENCES}

[1] Tu'u, Tulus, (The Role of Discipline to the Student's Beahvior and Achievement) "Peran Disiplin pada Perilaku dan Prestasi Siswa", Jakarta: Grasindo, 2004.

[2] Notoatmodjo, Sukidjo, (Human Resources Development) "Pengembangan Sumberdaya Manusia", Jakarta: Rineka Cipta, 2009.

[3] Simamora, Bilson, (Marketing Research) "Riset Pemasaran," Jakarta: Gramedia Utama, 2004.

[4] Fathoni, Abdurrahmat, (Organization and Human Resources Management) "Organisasi dan Manajemen Sumber Daya Manusia," Jakarta: PT Rineka Cipta, 2006.

[5] Hasibuan, Malayu S.P., (Human Resources Management) "Manajemen Sumber Daya Manusia,” Jakarta: Bumi Aksara, 2002.

[6] Girdano, Daniel A., and George S. Everly, "Controlling Stress and Tension”, The University of Michigan: Prentice-Hall, 1979.

[7] Winarsunu, Tulus, (Statistic in the Psychology's Research and Research) "Statistik Dalam Penelitian Psikologi dan Penelitian", Malang: UMM Press, 2008.

[8] Sunarso, (The Influence of Leadership, Disciplince, Work Load and Work Motivation to the Teacher School Performance) "Pengaruh Kepemimpinan, Kedisiplinan, Beban Kerja dan Motivasi Kerja terhadap Kinerja Guru Sekolah”, Jurnal Managemen Sumber Daya Manusia. Vol 4. No 1 (2010).

[9] Manuaba, (The Relation of Work Load and Work Capacity) "Hubungan Beban Kerja Dan Kapasitas Kerja,” Jakarta: Rinek Cipta, 2000. 